\title{
Pengaruh Pendidikan Anak Usia Dini terhadap Prestasi Belajar Siswa Kelas I Sekolah Dasar di Kabupaten dan Kota Tangerang
}

\author{
Aceng Lukmanul Hakim \\ Dosen FKIP UNIS Tangerang
}

\begin{abstract}
Abstrak: Pendidikan anak usia dini adalah lembaga yang menyelenggarakan pendidikan formal bagi anak-anak yang berumur 0-6 tahun sebelum memasuki sekolah dasar. Lembaga ini membantu melanjutkan pendidikan yang dasar-dasarnya telah diletakkan oleh orang tua dalam keluarga, sedangkan sekolah dasar adalah lembaga pendidikan yang dipersiapkan bagi anak-anak umur 6-13 tahun guna memasuki jenjang pendidikan selanjutnya. Siswa sekolah dasar yang mengikuti pendidikan anak usia dini lebih berprestasi dari pada siswa yang tidak mengikutinya. Prestasi ini tidak hanya pada aspek intelektual, namun juga aspek psikomotorik, nilai dan sikap dengan perbedaan yang signifikan. Prestasi ini pun tidak hanya di Kota Tangerang, melainkan juga di Kabupaten Tangerang. Di pihak lain kepala sekolah dasar dan guru kelas I di Kota Tangerang cenderung memiliki cara pandang terhadap pendidikan lebih tinggi dari pada di Kabupaten Tangerang.
\end{abstract}

Kata-kata Kunci: pendidikan anak usia dini, prestasi belajar.

\begin{abstract}
Early Childhood Education (ECE) is an institute carrying out a formal education for children age 0-6 before entering elementary school. This foundation aims to continue the education as well as to execute parents's commendation that has been putting down in the family, where as the elementary school (ES) is the institution of education that prepared children age 6-13 for entering next education. The students of elementary school, who were from early childhood education have shown up achievement compared to those who were not. This achievement is not only in intellectual aspec, but in psychomotoric aspec, value and attitude with a significant performant. That achievement is not only at Tangerang City, but at Tangerang Major. On the other hand hadmaster and the teacher's first class in elementary school at Tangerang City inclined have a way of view of education more higher than at Tangerang Major.
\end{abstract}

Key words: early childhood education, learning achievement

\section{Pendahuluan}

Sejak lahir manusia pada dasarnya telah belajar, bahkan ketika masih dalam kandungan mereka telah belajar. Lingkungan pendidikan pertama tempat anak belajar adalah keluarga (primay group) yang merupakan lingkungan pendidikan informal. Pengaruh keluarga dan lingkungan (pendidikan nonformal/informal) dalam pembentukan pribadi anak adalah diketahui dan diakui secara universal, namun mereka perlu dibimbing ke arah perkembangan yang optimal melalui jalur pendidikan formal yang berbentuk taman kanak-kanak (TK) dan/atau raudlatul athfal (RA). Lembaga ini meneruskan pembinaan sekaligus mengemban amanat orang tua yang dasar-dasarnya telah diletakkan di dalam lingkungan keluarga serta menerima tanggung jawab pendidikan berdasar kepercayaan keluarga. Selain itu, lembaga pendidikan ini tidak saja memberikan kesempatan kepada anak-anak untuk lebih jauh mengembangkan tingkah lakunya, tapi juga menambah semangat ke arah terbentuknya tingkah laku sosial, kecakapan serta keterampilan-keterampilan (Hakim, 1996).

Seperti diketahui, kemajuan masyarakat berpikir jauh ke depan tentang pendidikan, memotivasi mereka untuk mempersiapkan anak sejak dini dengan memasukkannya ke lembaga pendidikan anak usia dini. Namun demikian, hal itu bukanlah satu-satunya alasan, kecenderungan yang terjadi sekarang disebabkan oleh karena kesibukan orang tua atau pun keterbatasan kemampuan dan pengetahuan mereka dalam mendidik anak-anak. Di samping itu, ada pula sikap orang tua yang sekedar mengikuti trend yang sedang digandrungi walau dengan cara 
memaksakan diri, dsb. Meskipun demikian, mereka berharap bahwa anak-anak dapat berkembang, baik kognitif, afektif maupun psikomotoriknya, sehingga bisa berprestasi pada jenjang pendidikan berikutnya. (Isya, 2005).

Kecenderungan itu, telah mendorong bermunculannya lembaga-lembaga pendidikan anak usia dini baik formal maupun nonformal, tidak hanya di kota-kota besar, melainkan di pelosokpelosok perkampungan. Saat ini terdapat berbagai bentuk lembaga pendidikan anak usia dini di Indonesia, seperti: taman kanak-kanak (TK), taman kanak-kanak Islam (TKI), taman kanakkanak Islam terpadu (TKIT), taman pendidikan Al-qur'an (TPA) dan ta'limul qur'an lil aulad (TQA), home schooling, dsb.

Mengingat kondisi masyarakat Indonesia, khususnya di Kabupaten dan Kota Madya Tangerang memiliki tingkat sosial dan tarap hidup yang berbeda-beda, maka tidak heran apabila kebanyakan dari mereka terutama yang berpendapatan rendah beranggapan, bahwa pendidikan anak usia dini tidak terlalu penting (mengingat biayanya juga mahal), ijazahnya tidak dijadikan syarat untuk memasuki jenjang pendidikan berikutnya, yaitu sekolah dasar dan/ atau sederajat.

Hal itu di antaranya yang menimbulkan perbedaan kemampuan pada siswa kelas I sekolah dasar yang terlebih dahulu mengikuti pendidikan anak usia dini (formal) dengan yang tidak mengikutinya (nonformal/informal). Perbedaan lain dapat dilihat dari segi cara bersosialisasi baik dengan guru maupun dengan teman sebayanya, cara menerima materi pelajaran, cara menyelesaikan tugasnya, dll. Untuk selanjutnya pemakaian kata Kabupaten Tangerang disingkat Kabupaten, sedang Kota Madya Tangerang disingkat Kota.

Berdasarkan latar belakang masalah tersebut, maka dirumuskan masalahnysebagai berikut: 1) Apakah ada perbedaan prestasi antara siswa kelas I sekolah dasar semester I tahun pelajaran 2008/2009 yang sebelumnya pernah mengikuti pendidikan anak usia dini (formal) dengan yang tidak mengikuti pendidikan formal (nonformal/informal) di Kabupaten dan Kota Tangerang? 2) Jika ada, seberapabesarkah perbedaan tingkat prestasi itu? dan 3)
Bagaimanakah pengaruh pendidikan anak usia dini terhadap perolehan/pencapaian prestasi siswa sekolah dasar kelas I semester I, baik siswa yang berasal dari pendidikan anak usia dini (formal) maupun nonformal/informal tahun pelajaran 2008/2009 di Kabupaten dan Kota Tangerang?

Penelitian ini bertujuan untuk mengetahui: 1) Tingkat perbedaan pencapaian prestasi belajar siswa sekolah dasar kelas I semester I tahun pelajaran 2008/2009 antara siswa yang pernah mengikuti pendidikan anak usia dini (formal) dengan siswa yang tidak mengikuti pendidikan formal (nonformal/informal) di Kabupaten dan Kota Tangerang; 2) Besarnya tingkat perbedaan prestasi antara siswa yang berasal dari pendidikan anak usia dini (formal) dengan nonformal/informal; dan 3) Pengaruh pendidikan anak usia dini terhadap pencapaian prestasi belajar siswa sekolah dasar kelas I semester I, baik siswa yang berasal dari pendidikan anak usia dini (formal) maupun nonformal/informal tahun pelajaran 2008/2009 di Kabupaten dan Kota Tangerang.

\section{Kajian Literatur Pendidikan Anak Usia Dini}

Dalam hal ini terdapat beberapa ahli yang mengemukakan pendapatnya tentang pendidikan, Driyarkara (1980) dalam Mikarsa, menyatakan, pendidikan adalah upaya memanusiakan manusia muda. (Mikarsa, dkk, 2007). Pandangan senada dikemu-kakan Winkel bahwa pendidikan ialah bantuan yang diberikan oleh orang dewasa kepada orang yang belum dewasa agar ia mencapai kedewasaan. (Winkel, 1991).

Tim dosen IKIP Malang mengemukakan bahawa: a) Pendidikan adalah aktivitas dan usaha manusia untuk meningkatkan kepri-badiannya dengan jalan membina potensi-potensi pribadinya, yaitu jasmani dan rohani; b) Pendidikan berarti juga lembaga yang bertanggung jawab menetapkan tujuan, isi, sistem dan organisasi pendidikan. Lembaga ini meliputi: keluarga, sekolah dan masyarakat; dan c) Pendidikan merupakan tingkat kemajuan masyarakat dan kebudayaan sebagai suatu kemajuan. (Tim Dosen IKIP Malang, 1998). 
UU. No. 20 Tahun 2003 tentang Sistem Pendidikan Nasional Bab I pasal 1: Pendidikan adalah usaha sadar terencana untuk mewujudkan suasana belajar dan proses pembelajaran agar peserta didik secara aktif mengembangkan potensi dirinya untuk memiliki kekuatan spiritual keagamaan, pengendalian diri, kecerdasan, akhlak mulia serta ketrampilan yang diperlukan dirinya, masyarakat dan bangsa. (UU, No. 20/2003). Ini berarti bahwa pendidikan tersebut adalah sebuah upaya yang disadari dalam upaya meningkatkan potensi, yaitu prestasi siswa di kelas I sekolah dasar.

Selanjutnya, pendidikan anak usia dini adalah suatu upaya pembinaan yang ditujukan kepada anak sejak lahir sampai usia enam tahun yang dilakukan melalui pemberian rangsangan pendidikan untuk membantu pertumbuhan dan perkembangan jasmani dan rohani agar anak memiliki kesiapan dalam memasuki pendidikan lebih lanjut (UU. No. 20/2003).

Di sini timbul pertanyaan, apakah perlu memasukkan anak-anak ke pendidikan anak usia dini (formal) sebelum mereka memasuki sekolah dasar dan apakah manfaatnya bagi masyarakat maupun bagi kanak-kanak pada usia tersebut?

Untuk mengetahui manfaat pendidikan anak usia dini ini, maka bisa melihat tujuan Fredrick Frobel mendirikan Taman Kanak-Kanak, sbb: a) mendirikan pendidikan yang lengkap kepada anak-anak ( \pm 3-6 tahun) sesuai perkembangannya yang wajar, karena pendidikan di rumah tidak mencukupi; b) memberikan pertolongan dan bimbingan kepada para ibu dalam mendidik anak; c) mendidik anak dan menyiapkan para calon ibu dalam teori dan praktik untuk menjadi pendidik untuk tugasnya sebagai ibu dikemudian hari. (dalam Purwanto, 1998).

Adapun fungsi taman kanak-kanak dan raudlatul athfal seperti dijelaskan di dalam kurikulum 2004 yaitu untuk: a) mengenalkan peraturan dan menanamkan disiplin pada anak; b) mengenalkan anak dengan dunia sekitar; c) menumbuhkan sikap dan perilaku yang baik; c) mengembangkan kemampuan berkomunikasi dan bersosialisasi; d) mengembangkan ketrampilan, kreativitas dan kemampuan yang dimiliki anak; dan e) menyiapkan anak untuk memasuki pendidikan dasar (Depdiknas, 2003).
Tujuan pendidikan anak usia dini (prasekolah) yaitu untuk membantu anak didik mengembangkan berbagai potensi baik psikhis dan fisik yang meliputi moral dan nilai-nilai agama, sosial emosional, kognitif, bahasa, fisik/motorik, kemandirian dan seni untuk siap memasuki pendidikan dasar. (Depdiknas, 2003).

\section{Pendidikan (Sekolah) Dasar}

Sekolah dasar (SD) menurut Waini Rasyidi merupakan satuan atau unit lembaga sosial (social institution) yang diberi amanah atau tugas khusus (specific task) oleh masyarakat untuk menyelenggarakan pendidikan dasar secara sistematik. Secara teknis operasional, pendidikan/sekolah dasar dapat diartikan sebagai proses membimbing, mengajar dan melatih peserta didik yang berusia antara $6-13$ tahun untuk memiliki kemampuan dasar dalam aspek intelektual, sosial dan personal yang terintegrasi dan sesuai dengan karakteristik perkembangannya (Mikarsa, dkk, 2007). UU. No. 20 tahun 2003, pasal 17 ayat (1) menyatakan, pendidikan dasar merupakan jenjang pendidikan yang melandasi jenjang pendidikan menengah (UU. No. 20/2003).

Secara umum sekolah memiliki 3 fungsi utama, yaitu: a) Sekolah berfungsi sebagai lembaga sosial, membantu anak mempelajari cara-cara hidup dimana mereka tinggal; b) Sekolah berfungsi untuk mentransmisi dan mentransformasi kebudayaan; dan d) Sekolah berfungsi menyeleksi murid untuk melanjutkan pendidikan yang lebih tinggi (Mikarsa, dkk, 2007).

Fungsi pendidikan di sekolah dasar yang mengacu pada tujuan pendidikan nasional, yaitu mengembangkan kemampuan dan meningkatkan mutu kehidupan, harkat dan martabat manusia dan masyarakat Indonnesia, dengan tidak melupakan berakhlak mulia dan berbudi luhur (Mikarsa, dkk, 2007).

Melihat uraian di atas, Ahnan (1986) dalam Mikarsa, dkk, menyatakan, dengan adanya perkembangan dan perubahan zaman, maka pendidikan di sekolah da-sar perlu reorientasi, terutama berkenaan dengan aspek tujuan, pandangan terhadap perkembangan anak, proses pembelajaran serta evaluasinya (Mikarsa, dkk, 2007).

Sejalan dengan itu, Rochman Natawidjaja 
(1989) menyatakan bahwa: a) Program pendidikan di sekolah dasar perlu lebih memperhatikan tingkat perkembangan kognitif dan afektif siswa, sehingga pendidikan yang diberikan menjadi lebih bermakna; b) Proses pendidikan di sekolah dasar perlu lebih ditekankan pada upaya agar siswa mau dan mampu belajar berdasar kebermaknaan belajarnya; dan c) Evaluasi terhadap keberhasilan siswa harus didasarkan pada tujuan program sebagai tolok ukur dan dikaitkan dengan pemberian dasar-dasar keberhasilan belajar pada jenjang pendidikan berikutnya serta keberhasilan hidup di masyarakat (dalam Mikarsa, dkk, 2007).

Semenjak ditetapkannya wajib belajar (wajar) sembilan tahun, fungsi sekolah dasar mengalami perubahan mendasar. Sekolah dasar tidak lagi menjalankan fungsinya sebagai fungsi terminal, melainkan fungsi transisional. Artinya, bagi setiap anak sekolah yang berumur 6 - 13 tahun yang menamatkan pendidikannya di SD bukanlah merupakan tahap akhir dari pendidikan formal, melainkan sebagai tujuan antara, karena setelah itu semua pihak harus membantu mereka untuk melanjutkan ke pendidikan selanjutnya, yaitu SLTP dan/atau sederajat.

Oleh karena itu, fungsi pendidikan di sekolah dasar yaitu berfungsi untuk: a) Fungsi edukatif, ini lebih menonjol dibanding dengan fungsi pengajaran. Fungsi tadi diwujudkan dalam bentuk modeling, yaitu memberikan contoh konkrit; dan b) Fungsi pengembangan dan peningkatan, yang merujuk pada upaya optimalisasi potensi siswa melalui penciptaan lingkungan pembelajaran yang kondusif (Mikarsa, dkk, 2007).

Adapun tujuan pendidikan di sekolah dasar dimaksudkan untuk: a) memberi bekal kemampuan membaca, menulis dan berhitung; b) memberikan pengetahuan dan ketrampilan dasar yang bermanfaat bagi siswa sesuai dengan tingkat perkembangannya; c) mempersiapkan siswa untuk mengikuti pendidikan di SLTP (Mikarsa, dkk, 2007).

\section{Perkembangan Anak Usia Dini}

Seperti diyakini oleh Montessori dalam Hainstock, setiap anak memiliki periode-periode sensitif pertumbuhan, yaitu lahir dari: a) 0 sampai 3 tahun: pikiran dapat menyerap pengalaman-pengalaman sensoris; b) 1,5-3,0 tahun: perkembangan bahasa, c) 1,5-4,0 tahun: koordinasi dan perkembangan otot, minat pada benda-benda kecil; d) 2,0 - 4,0 tahun, meliputi: peneguhan gerakan, minat pada kebenaran dan realitas, menyadari urutan dalam waktu dan ruang; e) 2,56,0 tahun: peneguhan sensoris; f) 3,0-6,0 tahun: rawan pengaruh orang dewasa; g) 3,5-4,5 tahun : ketrampilan menulis; h) 4,0-4,5 tahun: kepekaan indra; dan i) 4,5-5,5 tahun: ketrampilan membaca (Hainstock, 2002).

Periode ini disebut periode sensitif, disebut juga golden age atau usia emas. Pada usia tersebut seorang anak dapat menyerap segala pelajaran dengan baik dan mudah. Untuk itulah penting sekali memberi pelajaran sejak usia dini pada anak, baik secara formal, informal maupun nonformal.

Menurut Carolyn Triyon dan Lilienthal, terdapat beberapa tugas perkem-bangan masa kanak-kanak awal yang harus dijalani dimasa prasekolah, sbb: a) berkembang menjadi mandiri; b) belajar mandiri, berbagi dan memperoleh kasih sayang; c) belajar bergaul dengan anak lain; d) mengembangkan pengendalian diri; e) belajar bermacam-macam peran orang dalam masyarakat; f) belajar untuk mengenal anggota tubuh masing-masing; g) belajar menguasai keterampilan motorik; h) belajar mengenal lingkungan fisik dan mengendalikannya; i) belajar menguasai kata-kata baru untuk memahami anak/orang lain; dan j) mengembangkan perasaan positif dalam berhubungan dengan lingkungan (dalam Moeslichatoen R, 2004).

\section{Proses Pendidikan pada Pendidikan Anak Usia Dini}

Penguasaan guru tentang wawasan tugas perkembangan anak sangatlah membantu dalam membuat metode dan merencanakan program kegiatan belajar bagi anak. Dalam memilih suatu metode yang akan dipergunakan dalam program kegiatan pendidikan anak usia dini, guru perlu memahami alasan yang kuat serta faktor-faktor yang mendukung pemilihan metoda tersebut.

Menurut Moeslichatoen tidak semua hasanah metode pengajaran cocok dengan program kegiatan di taman kanak-kanak (pendidikan anak usia dini). Berikut merupakan metode-metode 
pengajaran yang sesuai dengan karakteristik anak usia tersebut, sbb: 1) Bermain, pemanfaatannya dalam program pendidikan anak usia dini menjadi syarat mutlak. Bagi anak belajar adalah bermain dan bermain sambil belajar; 2) Karyawisata, siswa berkesempatan untuk mengobservasi, memperoleh informasi atau mengkaji segala sesuatu secara langsung. Anak dapat belajar dari pengalaman, sekaligus melakukan generalisasi berdasar sudut pandang mereka; 3) Bercakap-cakap, penggunaan metode bercakap-cakap bagi anak usia dini akan membantu perkembangan dimensi sosial, emosi, kognitif dan bahasa; 4) Bercerita, bercerita merupakan cara untuk meneruskan warisan budaya dari generasi ke generasi, sekaligus menjadi media untuk menyampaikan nilai-nilai yang berlaku di masyarakat; 5) Demonstrasi. Melalui ini diharapkan akan dapat mengenal langkah-langkah pelaksanaan suatu aktivitas; 6) Proyek. Cara ini dapat menggerakkan anak untuk melakukan kerja sama sepenuh hati secara terpadu untuk mencapai tujuan bersama; 7) Pemberian Tugas. Mereka dapat melaksanakan kegiatan secara nyata dan tuntas, baik perorangan maupun kelompok (Moeslichatoen $\mathrm{R}$, 2004).

Dengan demikian, belajar adalah sebuah proses dari pendidikan dan pengalaman yang dapat menimbulkan perubahan tingkah laku dan respon-respon baru sekaligus meningkatkan prestasi.

\section{Prestasi (Hasil) Belajar}

Prestasi diartikan sebagai suatu tingkatan keberhasilan belajar. Prestasi ini diperoleh dengan mengevaluasi hasil belajar siswa. Evaluasi artinya penilaian tehadap tingkatan keberhasilan siswa mencapai tujuan yang telah ditetapkan dalam sebuah program (Syah, 1996). Evaluasi ini terutama dilakukan oleh guru, dan melalui ini dapat diketahui keadaan dan kemampuan belajar siswa. Sedang prestasi belajar adalah penguasaan pengetahuan dan ketrampilan yang dikembangkan oleh mata pelajaran, lazimnya ditunjukkan dengan nilai test atau angka yang diberikan oleh guru (Alwi, 2001). Menurut Nana Sudjana, hasil atau prestasi belajar adalah kemampuankemampuan yang dimiliki siswa setelah ia menentukan pengala-man belajarnya. (Sudjana, 1996). Jadi prestasi ini merupakan suatu bukti keberhasilan usaha yang dicapai seseorang setelah melakukan suatu kegiatan. (Rusyan, 2000).

Dalam hal ini terdapat beberapa faktor yang mempengaruhi aktivitas belajar. Azhari, mengemukakan bahwa belajar dipengaruhi oleh dua faktor, yaitu: 1) Faktor Intrinsik, yang berasal dari dalam diri pelajar, meliputi: kondisi fisik siswa, kesehatan dan kekuatan jasmani siswa. Yang lain adalah aspek psikologis, yaitu aspek kejiwaan siswa. 2) Faktor Ekstrinsik, yang berasal dari luar diri siswa, meliputi aspek non sosial, seperti: kondisi alam di sekitar, udara, cuaca, peralatan belajar, dll. Hal ini mesti dikondisikan agar memberikan kenyamanan. Aspek sosial meliputi hubungan dengan manusia atau masyarakat sekitar, seperti teman sebaya, adik, kakak, dsb. (Azhari, 1996).

Gagne mengelompokkan katagori hasil belajar siswa menjadi lima, sbb: informasi verbal, kemahiran intelektual, pengaturan kegiatan kognitif, ketrampilan motorik dan Sikap (attitude) (dalam Winkel, 1991).

Mengutip pendapat para ahli, Mudzakir mengungkapkan bahwa belajar merupakan suatu proses yang harus melewati beberapa tahapan/ fase belajar. Gagne membagi fase belajar menjadi delapan, sbb: fase motivasi, fase konsentrasi, fase mengolah, fase dimasukkan ke dalam ingatan, fase menggali dari ingatan, fase generalisasi, fase memberikan prestasi dan fase feedback (dalam Syah, 1996). Menurut Bruner, siswa menempuh tiga fase dalam belajar, sbb: fase informasi, fase trans-formasi, fase evaluasi (dalam Syah, 1996). Wittig (1981) memiliki pendapat yang ham-pir sama, sbb: Acquisition, yaitu perolehan atau penerimaan informasi, Storage, penyimpanan informasi, Retrieval, mendapatkan kembali informasi (dalam Syah, 1996).

Prestasi ini pun pada dasarnya didorong dengan adanya minat. Minat dapat menimbulkan rasa senang pada setiap aktivtas yang dilakukannya. Jika anak berminat pada suatu aktivitas, maka pengalamannya akan dirasa sangat menyenangkan, sebaliknya jika anak gagal, maka pengalaman tersebut akan dirasa sangat tidak menyenangkan (Mikarsa, dkk, 2007). 
Dari uraian di atas, dapat disimpulkan bahwa prestasi belajar siswa adalah suatu tingkat keberhasilan yang dicapai oleh siswa dalam penguasaan terhadap ilmu pengetahuan atau keterampilan yang dilandasi dengan perubahan tingkah laku yang pada umunya diketahui dengan mengevaluasi hasil belajar.

\section{Pengaruh Pendidikan Anak USia Dini Terhadap Prestasi Belajar Siswa}

Supriadi (2004) menjelaskan hasil penelitian yang dilakukan oleh National Institute for Educational Research (NIER) di Jepang tentang pengaruh pendidikan anak usia dini (hoikusho dan yochien) terhadap prestasi belajar anak setelah berada di sekolah dasar, sbb: 1) Anak-anak yang pernah mengikuti pendidikan anak usia dini memiliki pengaruh yang signifikan terhadap prestasi belajar mereka. 2) Anak-anak yang belajar di taman kanak-kanak selama dua tahun pengaruhnya lebih nyata terhadap prestasi belajar mereka ketika di SD dibanding dengan belajar satu tahun atau tiga tahun (dalam Anam, 2007).

M. Sardja (1981) dalam disertasinya di IKIP Jakarta menjelaskan: 1) Pengalaman anak-anak selama di taman kanak-kanak mempengaruhi secara nyata terhadap prestasi belajar membaca dan matematika siswa kelas I SD di Jakarta. 2) Anak-anak yang sebelumnya tidak pernah belajar di taman kanak-kanak, saat di kelas I SD lebih sering mengalami kesulitan belajar membaca dibanding dengan murid-murid yang sebelumnya masuk TK. (dalam Anam, 2007).

Hasil penelitian Direktorat Pendidikan Dasar Depdiknas (2000) menunjukkan pendidikan taman kanak-kanak memiliki kontribusi terhadap kesiapan belajar siswa di kelas I SD. Kontribusi ini terjadi pada semua aspek kesiapan belajar, mulai bahasa, kecerdasan, sosial, motorik, moral, perasaan, daya cipta dan kedisiplinan. (dalam Anam, 2007). Begitu pula dengan hasil penelitian Balitbang (2004) menunjukkan, terdapat 841.662 siswa SD/MI yang mengulang kelas mulai kelas I - VI: Kelas I sebanyak 292.462 siswa, kelas II sebanyak 165.888 siswa, kelas III sebanyak 131.159 siswa, kelas IV sebanyak 94.829 siswa, kelas $V$ sebanyak 56.776 siswa, kelas VI sebanyak 8.424 siswa. Sedangkan yang mengulang di MI mulai kelas I sampai dengan VI adalah
92.124 siswa. (dalam Anam, 2007).

Diah Harianti Kapuskur Depdiknas, mengatakan bahwa permasalahan utama anak yang baru masuk SD adalah school readiness, di samping banyak hal yang melatarbelakangi kondisi anak mau masuk SD, seperti: kondisi fisik bawaan anak dan kondisi fisik rumah yang sangat mempengaruhi tumbuh kembang anak; kondisi psikososial anak di rumah; perbedaan pendidikan di rumah dengan di sekolah; saat belajar di rumah, interaksi terjadi antara satu orang dengan satu orang lainnya, misalnya antara orang tua dengan anaknya, sedang di sekolah antara satu orang guru dengan siswa satu kelas; anak tumbuh dengan kecerdasan yang berbeda (individual differential treatment). Selain itu, situasi, kesibukan dan kebiasaan orang tua di rumah turut melatarbelakangi kondisi anak masuk SD. Misalnya kesibukan kerja, sulitnya membagi waktu, dan sebagainya.

Selain itu terdapat pula beberapa hal yang memberatkan anak, yaitu: 1) Anak yang baru masuk SD langsung diperlakukan seperti anakanak kelas tinggi; dan 2) Guru kelas awal langsung menggunakan bahasa Indonsia, padahal itu membuat prestasi anak menjadi turun terutama di SD-SD pedesaan, menurut Husni Muadz, Kapuslit Bahasa dan Kebudayaan Universitas Mataram-Nusa Tenggara Barat. Jika mau berhasil secara akademis maupun kultural, kelas-kelas awal harus menggunakan bahasa ibu, kecuali jika memang dari awalnya menggunakan bahasa Indonesia; 3) Muhammad Ali mengatakan bahwa sarana dan prasarana fisik serta kualitas sumber daya manusia sekolah yang kurang mendukung terlaksananya pembelajaran yang baik di SD-SD, terutama SD Inpres (Anam, 2007).

Dari uraian di atas, diambil kesimpulan bahwa anak-anak yang mengulang kelas (kurang berprestasi) pada umumnya adalah anak-anak yang tidak memasuki pendidikan prasekolah sebelum masuk SD. Mereka adalah anak yang belum siap dan tidak dipersiapkan oleh orang tuanya memasuki SD. Adanya perbedaan yang besar antara pola pendidikan di sekolah dan di rumah menyebabkan anak yang tidak masuk pendidikan prasekolah mengalami kejutan, mereka mogok sekolah karena tidak mampu menyesuaikan diri, sehingga tidak dapat 
berkembang secara optimal. Hal ini menunjukkan pentingnya upaya pengembangan seluruh potensi anak semenjak usia dini. Ini berarti, pendidikan taman kanak-kanak atau prasekolah memiliki potensi sangat strategis dalam meningkatkan prestasi belajar dan mencegah putus sekolah.

Melalui proses pendidikan, pada gilirannya dapatlah diketahui tingkat perkembangan kemampuan mereka, baik siswa yang berasal dari pendidikan anak usia dini (formal) maupun nonformal sehingga bisa berprestasi di kelasnya (sekolah).

\section{Kerangka Pemikiran}

Di bawah ini disajikan gambar alur kerangka berpikir penulis sebagai berikut.
Hipotesis 2:

$\mathrm{Ho}=$ Tidak terdapat pengaruh positif pendidikan anak usia dini terhadap prestasi

belajar siswa di kelas I sekolah dasar di Kota Tangerang ( $\left.\mathrm{Ho}: r_{2}=0\right)$.

$\mathrm{Ha}=$ Terdapat pengaruh positif pendidikan anak usia dini terhadap prestasi belajar siswa di kelas I sekolah dasar di Kota Tangerang ( $\mathrm{Ha}: r_{2}>0$ ).

Hipotesis 3:

Ho = Tidak terdapat pengaruh positif pendidikan anak usia dini terhadap prestasi belajar siswa di kelas I sekolah dasar di Kabupaten maupun di Kota Tangerang ( $\mathrm{Ho}: r_{3}=0$ ).

$\mathrm{Ha}=$ Terdapat pengaruh positif pendidikan anak usia dini terhadap prestasi belajar siswa

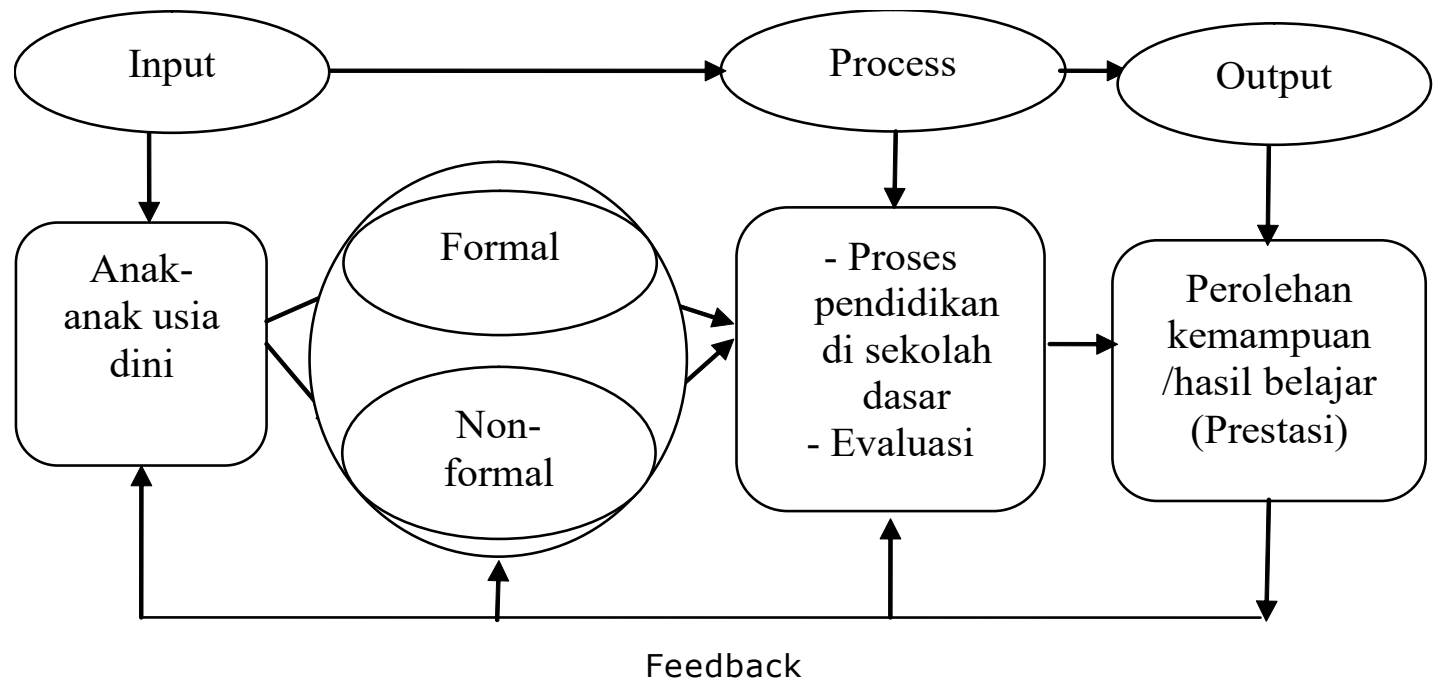

Gambar 1. Alur proses pembelajaran siswa kelas I sekolah dasar di Kabupaten Tangerang dan Kota Madya Tangerang

\section{Hipotesis}

Dari bahasan tersebut, penulis membuat hipotesis sebagai berikut:

\section{Hipotesis 1:}

$\mathrm{Ho}=$ Tidak terdapat pengaruh positif pendidikan anak usia dini terhadap prestasi belajar siswa di kelas I sekolah dasar di Kabupaten Tangerang ( $\left.\mathrm{Ho}: r_{1}=0\right)$.

$\mathrm{Ha}=$ Terdapat pengaruh positif pendidikan anak usia dini terhadap prestasi belajar siswa kelas I sekolah dasar di Kabupaten Tangerang ( $\mathrm{Ha}: r_{1}>0$ ). di kelas I sekolah dasar di Kabupaten maupun di Kota Tangerang ( $\mathrm{Ha}: \mathrm{r}_{3}>0$ ).

\section{Metode dan Obyek Penelitian}

Penelitian ini berpopulasikan seluruh siswa kelas I sekolah dasar di Kabupaten dan Kota Tangerang, tahun pelajaran 2008/2009 dengan obyek nilai prestasi siswa. Adapun sampel diambil pada 4 sekolah dasar negeri di 4 kecamatan di Kabupaten Tangerang dan 3 sekolah dasar negeri pada satu kecamatan di Kota Tangerang, waktu yang digunakan adalah bulan Agustus 2008.

Dilakukan pada bulan ini karena siswa yang 
pernah mengikuti pendidikan anak usia dini (formal) sudah bisa mengingat kembali pelajaran yang telah diberikan beberapa waktu lalu, sedang siswa yang tidak pernah mengikuti pendidikan formal sudah mulai diberikan pelajaran. Jadi kedua kelompok siswa sudah sama-sama mengenal pelajaran yang diberikan di kelas I sekolah dasar.

Metode yang digunakan deskriptif eksploratif, guna mengetahui hal-hal yang berhubungan dengan keadaan sesuatu yang menjelaskan apa adanya (Arikunto, S., 1998)

Variabel yang digunakan adalah pendidikan anak usia dini (formal) $(X) . X_{1}$ adalah siswa asal pendidikan anak usia dini dari Kabupaten Tangrang, $\mathrm{X}_{2}$ adalah siswa asal pendidikan nonformal/informal dari Kabupaten Tangerang, $X_{3}$ adalah siswa asal pendidikan anak usia dini (formal) dari Kota Tangerang dan $\mathrm{X}_{4}$ adalah siswa asal pendidikan nonformal/informal dari Kota Tangerang. Prestasi belajar siswa kelas I sekolah dasar adalah (Y). Adapun karakteristik variabel tersebut dijelaskan dalam Tabel 1.
Yang dijadikan populasi adalah seluruh siswa kelas I sekolah dasar di Kabupaten dan Kota Tangerang, sedang sampelnya diambil tujuh sekolah dasar tersebut di atas. Jumlah sampel di Kabupaten Tangerang (siswa asal pendidikan anak usia dini (formal): 128 orang dan nonformal/ informal: 50 orang), jadi 178 orang. Sedang di Kota Tangerang (siswa asal pendidikan anak usia dini (formal): 104 orang, dan nonformal/informal: 38), jadi 142 orang. Total sampel adalah 320 orang.

Penulis menggunakan teknik simple cluster sampling, dengan berasumsi seluruh siswa kelas I di Kabupaten dan Kota Tangerang memiliki kesempatan yang sama untuk dijadikan sampel. Sedang instrumen yang digunakan adalah teknik tes yang berupa tes prestasi belajar seperti: pengenalan angka dan hitungan, huruf dan pengenalan benda-benda, mencari pasangan gambar dan pasangan benda sejenis. Selain itu adalah teknik nontest, seperti observasi, interview dan questionnaire. Adapun langkah-langkahnya

Tabel 1. Karakteristik Variabel $X$ dan $Y$

\begin{tabular}{|c|c|}
\hline $\begin{array}{c}\text { Variabel } \mathrm{X}_{1} \text { dan }_{3} \\
\text { (Pendidikan Anak Usia Dini - Formal) }\end{array}$ & Variabel $\mathrm{Y}$ \\
\hline $\begin{array}{l}\text { 1. Siswa berasal dari pendidikan anak } \\
\text { usia dini. }\end{array}$ & $\begin{array}{l}\text { 1. Siswa memperoleh penglaman sebagai } \\
\text { entry behavior pada pendidikan } \\
\text { berikutnya. }\end{array}$ \\
\hline 2. Mendapat pendidikan formal. & $\begin{array}{l}\text { 2. Memiliki pengalaman belajar tidak } \\
\text { hanya dari keluarga (primary group) } \\
\text { dan lingkungan masyarakat. }\end{array}$ \\
\hline $\begin{array}{l}\text { 3. Orang tua mempersiapkan anak untuk } \\
\text { belajar di SD dengan memasukkannya } \\
\text { ke pendidikan anak usia dini. }\end{array}$ & $\begin{array}{l}\text { 3. Anak telah siap belajar di sekolah } \\
\text { dasar. }\end{array}$ \\
\hline $\begin{array}{l}\text { 4. Siswa sudah mengalami belajar di luar } \\
\text { rumah. }\end{array}$ & 4. Siswa bisa belajar secara mandiri. \\
\hline $\begin{array}{l}\text { 5. Siswa sudah terbiasa bersosialisasi } \\
\text { dengan banyak teman. }\end{array}$ & $\begin{array}{l}\text { 5. Siswa pandai bergaul, sehingga } \\
\text { mendapatkan banyak teman. }\end{array}$ \\
\hline $\begin{array}{l}\text { 6. Siswa sudah diperkenalkan pada } \\
\text { pelajaran walau melalui bermain. }\end{array}$ & $\begin{array}{l}\text { 6. Siswa sudah mengenal pelajaran dan } \\
\text { biasa belajar. }\end{array}$ \\
\hline
\end{tabular}

\begin{tabular}{|l|l|}
\hline \multicolumn{1}{|c|}{$\begin{array}{c}\text { Variabel } \mathrm{X}_{2} \text { dan } \\
\text { (Non-Formal/Informal) }\end{array}$} & \multicolumn{1}{|c|}{ Variabel Y } \\
\hline $\begin{array}{l}\text { 1. Siswa asal pendidikan anak usia dini } \\
\text { (non-formal/informal). }\end{array}$ & 1. Siswa belum kenal sekolah. \\
\hline 2. Tidak mendapat pendidikan formal. & $\begin{array}{l}\text { 2. Siswa tidak punya pengalaman pada } \\
\text { pendidikan formal. }\end{array}$ \\
\hline $\begin{array}{l}\text { 3. Orang tua tidak mempersiapkan anak } \\
\text { untuk belajar di SD dengan berbagai } \\
\text { alasan. }\end{array}$ & 3. Anak tidak siap belajar di sekolah dasar. \\
\hline $\begin{array}{l}\text { 4. Siswa belum mengalami belajar di luar } \\
\text { rumah. }\end{array}$ & $\begin{array}{l}\text { 4. Siswa masih agak kaku mengikuti } \\
\text { pelajaran. }\end{array}$ \\
\hline $\begin{array}{l}\text { 5. Siswa belum terbiasa bersosialisasi } \\
\text { dengan banyak teman. }\end{array}$ & 5. Siswa agak sulit bergaul. \\
\hline 6. Siswa belum mengenal pelajaran. & 6. Siswa belum bisa belajar. \\
\hline
\end{tabular}


sebagai berikut: 1) Pembuatan kisi-kisi soal test, (April-Juli 2008) yang berupa pernyataan (soalsoal tes). Adapun kisi-kisinya, sbb: a) Mengisi angka yang hilang 5 soal. b) Menghitung dan menjumlahkan benda 5 soal. c) Mengisi titik dengan huruf dengan tepat 5 soal. d) Mengenali benda-benda dan menulis namanya 5 soal. e) Mencari pasangan gambar 5 soal. f) Mencari pasangan benda sejenis 5 soal. Total 30 soal; 2) Pembuatan pedoman observasi, terdiri: 1) Aspek psikomorik, yang terdiri dari 3 indikator dan 7 subindikator. 2) Aspek sikap dan nilai, teridir dari 5 indikator dan 13 subindikator. Semua berjumlah 8 indikator dan 20 subindikator; dan 3) Soal yang terakhir berupa soal interview sekaligus angket tertutup, terdiri dari 10 soal, setiap pernyataan terdiri dari 5 option.

Sedang indikator yang diamati yaitu: 1) Bidang pengetahuan: kecerdasan (kemampuan mengenal kembali angka dan hitungan, huruf dan pengenalan benda, pasangan gambar dan pasangan benda sejenis), kemampuan menerima materi pelajaran, penyelesaian tugas dan kreativitas intelektual; 2) Bidang keterampilan: kreativitas berpikir dan berbuat; 3) Bidang sikap dan nilai: kesiapan menerima dan melaksanakan tugas, respons pada pelajaran, kestabilan emosi, keberanian dan kemandirian. Pada saatnya, soal tes diujicobakan di kelas IB, semester I Sekolah Dasar Negeri Jeungjing I, guna mengetahui normalitas dan homogenitas soal.

Dalam pengumpulan dan perekaman data ini, terdapat beberapa tahap, yaitu: 1) Persiapan, lembaran test langsung digunakan untuk lembar jawaban; 2) Pelaksanaan: (a) Tes dilakukan mulai tanggal 11 Agustus 2008, di beberapa sekolah yang telah disepakati, dengan mengambil waktu sampai dengan tanggal 30 Agustus 2008. Siswa diberikan soal/lembar jawaban. Waktu yang digunakan adalah 30 menit (1 jam pelajaran). Lembar jawaban dinilai dan dimasukkan ke daftar nilai test. Ialu diamati dan dianalisis, guna melihat siapa yang mendapat nilai 60-100 (mastery learning) dan siapa pula yang memperoleh nilai di bawah 60; (b) Selama riset diadakan observasi kepada para siswa kelas I sekolah setempat tentang kreativitas berpikir dan berbuat, kesiapan menerima dan melaksanakan tugas, respons terhadap pelajaran, kestabilan emosi, keberanian dan kemandirian. Adapun waktu yang dipergunakan untuk observasi ini tidak dibatasi hanya 30 menit bersamaan dengan test, melainkan lebih lama dan bahkan diluar jam pelajaran tadi; (c) Interview dan questionnaire, sebanyak 10 pertanyaan/ pernyata-an yang diberikan kepada guru kelas I dan kepala sekolah. Hal ini dilakukan guna mengetahui tanggapan mereka tentang prestasi belajar; 3) Teknik pemberian nilai, sehubungan nilai maksimum yang digunakan adalah 100, maka pencapaian nilai pun bisa dianalogikan dengan persentase $(\%)$; 4) Pada gilirannya dilakukan feedback, sharing pendapat dan masukan dalam wujud diskusi dan rekomendasi, guna menggali potensi intelektual, ketrampilan, sikap dan nilai siswa kelas I sekolah dasar tersebut.

Dalam tulisan ini terdapat dua jenis data, yaitu: 1) Data yang berwujud kualitatif, dianalisis dan diterjemahkan ke dalam persentase, dengan kriteria: (a) Jika hasil hitung persentase, menghasilkan tingkat keberhasilan belajar (prestasi) siswa asal pendidikan anak usia dini (formal) lebih tinggi dari pada siswa non-formal/ informal dan (b) Jika nilai rata-rata yang dicapai kedua kelompok siswa tersebut adalah mencapai mastery learning dan/atau mencapai kriteria ketuntasan minimal (KKM), maka hipotesis diterima. c) Jika sebaliknya, maka hipotesis ditolak. 2) Data yang berwujud kuantitatif, dianalisis dengan menggunakan a) regresi: $Y=a+b X ; b)$ t-test, (Sudiyono, 2008).

Untuk mendukung analisis data kuantitatif di atas, maka ditetapkan tarap signifikansi 95\%. Dari hasil pengujian hipotesis di atas, jika ha > ho, maka data yang diperoleh bisa dikatakan signifikan atau hipotesis diterima. Jika sebaliknya ha d" ho, maka data yang diperoleh tidak signifikan atau hipotesis ditolak.

\section{Hasil Penelitian dan Pembahasan Gambaran Siswa Asal Pendidikan Anak Usia Dini}

Dari hasil pengamatan secara umum, terlihat adanya perbedaan: a) Aktivitas sangat tinggi pada kelompok siswa asal pendidikan anak usia dini. Mereka cenderung lebih aktif dan b) Kecerdasan, kelompok siswa asal pendidikan anak usia dini dapat langsung memahami tugas 
yang diberikan dengan hanya satu kali penjelasan. Bahkan terdapat beberapa siswa yang tanpa mendengarkan penjelasan guru, langsung mengerjakan tugas (tes; c) Kecepatan mengerjakan tugas, dari 30 soal yang diberikan, kelompok siswa asal pendidikan anak usia dini dapat menyelesaikannya kurang dari 30 menit bahkan ada beberapa siswa yang menyelesaikannya hanya kira-kira 15 menit; d) Kreativitas mereka ditunjukkan untuk mengisi waktu tersisa dengan memberi warna untuk gambar pada soal-soal test yang berwujud gambar; e) Inisiatif dan kemandirian, semua pekerjaan yang diberikan dilakukannya sendiri tanpa saling menyamakan atau menyontek kepada siswa lain; f) Tidak banyak memerlukan pengawasan guru sewaktu mengerjakan tes.

Berbeda dengan kelompok siswa tersebut adalah kelompok siswa asal non-formal/nformal yang cenderung agak pasif (karena belum mengerti dan belum terbiasa menghadapi pelajaran). Kelompok ini membutuhkan pengawasan dan instruksi lebih banyak serta membutuhkan waktu rata-rata 30 menit (artinya lebih lama, walau sesuai standar).

\section{Hasil Try-Out Soal Tes.}

Senin, 4 Agustus 2008, pada jam sekolah, soal test diujicobakan di kelas IB, semester I Sekolah Dasar Negeri Jeungjing I, Hasilnya diamati dan dianalisis, lalu dilakukan uji normalitas dan iji homogenitas soal, sbb: a) Uji normalitas sederhana siswa asal pendidikan anak usia dini, posisi mean, median dan modus: 89,$68 ; 90,00$ dan 89,63 adalah hampir berada dalam 1 titik; b) Uji normalitas sederhana siswa asal non-formal/ informal, posisi mean, mediandan modus yaitu: 55,88; 56,20 dan 55,95 adalah hampir berada dalam 1 titik; dan c) Uji homogenitas soal, dengan kriteria: $F_{h}<F_{t}$. Jadi $0,4634<1,05$. Berarti soal untuk kedua kelompok siswa ini berdistribusi normal dan homogen.

\section{Data yang diperoleh dari penelitian.}

Data yang dipereoleh dari penelitin mencakup: a) Data rata-rata hasil tes, kelompok siswa asal pendidikan anak usia dini (formal) di Kabupaten Tangerang $\left(X_{1}\right)$ memperoleh nilai rata-rata 85,77; siswa asal nonformal/informal $\left(\mathrm{X}_{2}\right)$ adalah 71,38 ; jadi selisih 14,39. Sedang siswa asal pendidikan anak usia dini (formal) di Kota Tangerang $\left(X_{3}\right)$ adalah 90,07; siswa asal nonformal/informal $\left(X_{4}\right)$ adalah 70,95; jadi selisih 19,12; b) Data rata-rata hasil observasi, kelompok siswa asal pendidikan anak usia dini (formal) di Kabupaten Tangerang $\left(X_{1}\right)$ memperoleh nilai rata-rata 72,99 ; siswa asal nonformal/informal $\left(X_{2}\right)$ adalah 49,45; jadi selisih 22,83 . Sedang siswa asal pendidikan anak usia dini di Kota Tangerang $\left(\mathrm{X}_{3}\right)$ adalah 74,44 ; siswa asal nonformal/informal $\left(\mathrm{X}_{4}\right)$ adalah 60,65 ; jadi selisih 13,79 ; c) Data hasil questionnaire kepada para kepala sekolah dasar dan guru kelas I, sbb: untuk Kabupaten Tangerang $\left(X_{1}\right)$ adalah 61,25; sedang untuk Kota Tangerang $\left(X_{3}\right)$ adalah 73,33 . Namun secara keseluruhan antara $X_{1}$ dengan $X_{3}$ bernilai 87,92; sedang $X_{2}$ dengan $X_{4}$ adalah 71,16 ; jadi selisihnya adalah 13,76 .

\section{Pembahasan}

Analisis data berdasarkan pada persentase ditinjau dari tiga aspek, yaitu: 1) Aspek intelektual (tes), melihat nilai siswa $\left(X_{1}\right)$ dan $\left(X_{2}\right)$ memperoleh angka 85,77: 71,38. Sedang siswa $\left(X_{3}\right)$ dan $\left(X_{4}\right)$ memperlihatkan angka 90,07: 70,95; sbb: (a) Ditinjau dari sudut nilai intelektualitas, siswa $\left(X_{1}\right)$ memperlihatkan nilai yang lebih tinggi dari pada $\left(\mathrm{X}_{2}\right)$, begitu pula $\left(\mathrm{X}_{3}\right)$ lebih tinggi dari pada $\left(\mathrm{X}_{4}\right)$; (b) Ditinjau dari sudut wilayah, maka $\left(X_{3}\right)$ lebih tinggi dibanding dengan $\left(X_{1}\right)$. Sebaliknya, $\left(X_{3}\right)$ lebih tinggi dari pada $\left(\mathrm{X}_{4}\right)$. Ini memperlihatkan gambaran yang berbeda (walau tidak terlalu jauh); (c) Menurut rata-rata keseluruhan prestasi siswa, $\left(\mathrm{X}_{3}\right)$ dan $\left(\mathrm{X}_{4}\right)$, memperlihatkan gambaran nilai yang lebih tinggi dibanding $\left(X_{1}\right)$ dan $\left(X_{2}\right)$. Namun demikian, Kabupaten lebih menampakkan pemerataan prestasi dari pada Kota; (d) Dilihat dari sudut perbedaan nilai prestasi siswa, nampak adanya selisih angka dalam tabel analisis, yang hal itu bisa dianggap sebagai perbedaan tingkat prestasi yang dialami para siswa di masing-masing wilayah. Selisih nilai yang dialami para siswa di Kabupaten adalah 14,39, sedang di Kota memperlihatkan 19,12 . Perbedaan yang sangat jauh. Hal ini memberi petunjuk bahwa tingkat perbedaan prestasi para siswa di Kabupaten cenderung lebih kecil atau lebih merata, sedang prestasi di Kota memperlihatkan ketimpangan. Timbul pertanyaan: 1) Apakah perbedaan ini 
disebabkan karena nilai $\left(\mathrm{X}_{3}\right)$ di Kota sangat tinggi, sehingga meninggalkan nilai $\left(X_{1}\right)$ di Kabupaten? Padahal jika melihat nilai prestasi $\left(\mathrm{X}_{2}\right)$ dan $\left(\mathrm{X}_{4}\right)$ di kedua wilayah tersebut bisa dikatakan hampir sama, yaitu Kabupaten 71,39, sedang Kota 70,95. Nilai siswa di Kabupaten lebih tinggi dari pada di Kota; 2) Atau mungkinkah karena adanya perbedaan cara pandang dan pengelolaan pembelajaran siswa, baik di sekolah dasar maupun pada pendidikan anak usia dini di Kota maupun di Kabupaten, sehingga berpengaruh terhadap perbedaan prestasi siswa di kedua wilayah tersebut? (e) Pada aspek intelektual $\left(X_{1}\right)$ lebih tinggi dari pada $\left(X_{2}\right)$ dengan memperlihatkan pemerataan. $\left(X_{3}\right)$ lebih tinggi dari pada $\left(X_{4}\right)$ namun agak memperlihatkan ketimpangan. Di samping itu $\left(\mathrm{X}_{1}\right)$ dan $\left(\mathrm{X}_{3}\right)$ secara bersama-sama nampak lebih tinggi/berprestasi dari pada $\left(\mathrm{X}_{2}\right)$ dan $\left.\left(\mathrm{X}_{4}\right) ; 2\right)$ Aspek psikomotorik, nilai dan sikap (observasi), maka $\left(X_{1}\right)$ menunjukkan nilai 72,99 sedang $\left(X_{2}\right)$ adalah 49,45 . Jadi perbedaannya adalah 22,83 . Sebuah angka yang sangat jauh. Begitu pula dengan $\left(X_{3}\right)$ menunjukkan angka 74,44 ; sedang $\left(X_{4}\right)$ adalah 60,65 . Jadi perbedaannya 13,79 . Jika dibandingkan di antara keduanya, maka $\left(X_{1}\right)$ lebih tinggi dari $\left(X_{2}\right)$. Begitu pula $\left(X_{3}\right)$ lebih tinggi dari pada $\left(X_{4}\right)$. Secara bersama-sama $\left(X_{1}\right)$ dan $\left(X_{3}\right)$ lebih tinggi dari pada $\left(X_{2}\right)$ dan $\left.\left(X_{4}\right) ; 3\right)$ Aspek angket (questionnaire), mereka yang berasal dari Kabupaten memper-lihatkan angka 61,25 ; sedang Kota adalah 73,33. Jadi perbedaannya 12.08. Sebu-ah angka yang sangat jauh. Ini memberi petunjuk bahwa cara pandang para kepala sekolah dan guru kelas I sekolah dasar di Kota lebih maju dari pada di Kabupaten.

Secara keseluruhan bisa dikatakan, nilai siswa asal pendidikan anak usia dini lebih tinggi/lebih berprestasi dari pada siswa asal nonformal/ informal.
Analisis regresi dengan rumus: $Y=a+b X$. Dimana:

$$
\begin{aligned}
& b=\frac{n \sum X Y-\left(\sum X\right)\left(\sum Y\right)}{n\left(\sum X^{2}\right)-\left(\sum X\right)^{2}} \\
& a=\bar{Y}-b \bar{X} \\
& b=\underline{3(18526,6742)-(214,14)(257,31)} \\
& 3(15665,9348)-(214,14)^{2} \\
& =0,42 \\
& \bar{Y}=\frac{\sum \underline{Y}}{n}=\frac{257,31}{3}=85,77 \\
& \bar{x}=\frac{\sum \underline{x}}{n}=\frac{214,14}{3}=71,38 \\
& \mathrm{a}=85,77-0,42(71,38) \\
& =55,79 \\
& \text { Jadi } Y=55,79+0,42(71,38) \\
& =85,77
\end{aligned}
$$

Persamaan ini memiliki arti jika $X$ bertambah satu satuan nilai, maka $\mathrm{Y}$ akan bertambah sebesar 0,42 .

Mencari koefisien korelasi, dengan rumus:

$$
\begin{aligned}
r_{x y} & =\frac{\sum X Y}{\sqrt{\left(\sum X^{2}\right)\left(\sum Y^{2}\right)}} \\
& =\frac{18526,6742}{\sqrt{(15665,9348)(22246,6043)}} \\
& =0,99
\end{aligned}
$$

\section{Analisis Data Berdasar Regresi}

Tabel 2. Analisis data rata-rata untuk Kabupaten.

\begin{tabular}{|c|c|c|c|c|c|}
\hline NO & $\mathrm{X}$ & $\mathrm{Y}$ & $\mathrm{X}^{2}$ & $\mathrm{Y}^{2}$ & $\mathrm{XY}$ \\
\hline 1 & 62 & 88,75 & 3844 & 7876,5625 & 5502,5 \\
\hline 2 & 64,92 & 75,23 & 4214,6064 & 5659,5529 & 4883,9316 \\
\hline 3 & 87,22 & 93,33 & 7607,3284 & 8710,4889 & 8140,2426 \\
\hline$\sum$ & 214,14 & 257,31 & 15665,9348 & 22246,6043 & 18526,6742 \\
\hline Rata-rata & 71,38 & 85,77 & & & \\
\hline
\end{tabular}


Analisis koefisien determinat dengan rumus: $r_{d}=$ $r^{2}$

$$
\begin{aligned}
r_{d} & =0,99^{2} \\
& =0,98
\end{aligned}
$$

Pengolahan data dengan t-test

$$
\begin{aligned}
& t_{0}= \frac{r n-2}{\sqrt{1-r^{2}}} \\
&= \frac{0,99 \sqrt{3-2}}{\sqrt{1-0,98}} \\
& 7,07
\end{aligned}
$$

Berdasar $\mathrm{t}$ table didapat: $\mathrm{t}_{0}, 05(3)=0,997$. Jadi $7,07>0,997$. Berarti hubungan pendidikan anak usia dini (formal) dengan prestasi siswa kelas 1 sekolah dasar di Kabupaten adalah sangat kuat (signifikan). Hipotesis diterima.

$$
\begin{aligned}
\bar{x} & =\sum \frac{\mathrm{x}}{\mathrm{n}}=\frac{212,85}{3}=70,95 \\
\mathrm{a} & =90,07-0,1444(70,95) \\
& =79,82
\end{aligned}
$$

$$
\text { Jadi } \begin{aligned}
Y & =79,82+0,1444(70,95) \\
& =90,07
\end{aligned}
$$

Persamaan ini memiliki arti jika $X$ bertambah satu satuan nilai, maka $Y$ akan bertambah sebesar 0,1444 .

Mencari koefisien korelasi, dengan rumus:

$$
r_{x y}=\frac{\sum X Y}{\sqrt{ }\left(\sum X^{2}\right)\left(\sum Y^{2}\right)}
$$

$$
\begin{aligned}
& =\frac{19215,9374}{\sqrt{ }(15405,3203)(24348,9694)} \\
& =0,99
\end{aligned}
$$

Tabel 3. Analisis data rata-rata untuk Kota

\begin{tabular}{|c|c|c|c|c|c|}
\hline NO & $\mathrm{X}$ & $\mathrm{Y}$ & $\mathrm{X}^{2}$ & $\mathrm{Y}^{2}$ & $\mathrm{XY}$ \\
\hline 1 & 67,35 & 88,18 & 4536,0225 & 7775,7124 & 5938,923 \\
\hline 2 & 84,67 & 92,43 & 7169,0089 & 8543,3049 & 7826,0481 \\
\hline 3 & 60,83 & 89,61 & 3700,2889 & 8029,9521 & 5450,9763 \\
\hline$\sum$ & 212,85 & 270,22 & 15405,3203 & 24348,9694 & 19215,9374 \\
\hline Rata-rata & 70,95 & 90,07 & & & \\
\hline
\end{tabular}

Analisis regresi dengan rumus:

$$
\begin{aligned}
Y & =a+b X, \text { di mana: } \\
b & =\frac{n \sum X Y-\left(\sum X\right)\left(\sum Y\right)}{n\left(\sum X^{2}\right)-\left(\sum X\right)^{2}} \\
a & =\bar{Y}-\overline{b X} \\
b & =\frac{3(19215,9374)-(212,85)(270,22)}{3(15405,3203)-(212,85)^{2}} \\
& =0,1444 \\
\bar{Y} & =\frac{\sum Y}{n}=\frac{270,22}{3}=90,07
\end{aligned}
$$

Analisis koefisien determinat dengan rumus: $r_{d}=$ $r^{2}$

$$
\begin{aligned}
r_{d} & =0,99^{2} \\
& =0,98
\end{aligned}
$$

Pengolahan data dengan t-test

$$
\begin{aligned}
t_{0} & =\frac{r \sqrt{ } 3-2}{\sqrt{1-r^{2}}} \\
& =\frac{0,99 \sqrt{3}-2}{\sqrt{1-0,98}} \\
& =7,07
\end{aligned}
$$


Berdasar $\mathrm{t}$ tabel didapat: $\mathrm{t}_{0}, 05(3)=, 0,997$. Jadi $7,07>0,997$. Berarti hubungan pendidikan anak usia dini dengan prestasi siswa kelas 1 sekolah dasar di Kota Tangerang adalah sangat kuat (signifikan). Hipotesis diterima
Analisis koefosien determinat dengan rumus: $r_{d}$ $=r^{2}$

$$
\begin{aligned}
r_{d} & =0,99^{2} \\
& =0,98
\end{aligned}
$$

Tabel 4. Analisis regresi untuk rata-rata keseluruhan.

\begin{tabular}{|c|c|c|c|c|c|}
\hline NO & $X$ & $Y$ & $X^{2}$ & $Y^{2}$ & $X Y$ \\
\hline 1 & 62 & 88,75 & 3844 & 7876,5625 & 5502,5 \\
\hline 2 & 64,92 & 75,23 & 4214,6064 & 5659,5529 & 4883,9316 \\
\hline 3 & 87,22 & 93,33 & 7607,3284 & 8710,4889 & 8140,2426 \\
\hline 4 & 67,35 & 88,18 & 4536,0225 & 7775,7124 & 5938,923 \\
\hline 5 & 84,67 & 92,43 & 7169,0089 & 8543,3049 & 7826,0481 \\
\hline 6 & 60,83 & 89,61 & 3700,2889 & 8029,9521 & 5450,9763 \\
\hline$\Sigma$ & 426,99 & 527,53 & 31071,2551 & 46595,6037 & 37742,6216 \\
\hline Rata-rata & 71,165 & 87,92 & & & \\
\hline
\end{tabular}

Analisis regresi dengan rumus; $Y=a+b X$, di mana:

$$
\begin{aligned}
\mathrm{b} & =\frac{\mathrm{n} \sum \mathrm{XY}-\left(\sum X\right)\left(\sum Y\right)}{\mathrm{n}\left(\sum \mathrm{X}^{2}\right)-\left(\sum X\right)^{2}} \\
\mathrm{a} & =\bar{Y}-\mathrm{bY} \\
b & =6(37742,6216)-(426,99)(527,53) \\
& =\frac{6(31071,2551)-(426,99)^{2}}{0,29} \\
\bar{Y} & =\sum \underline{Y}=\frac{615,92}{6}=87,92 \\
\bar{X} & =\sum \underline{\mathrm{X}}=\frac{426,99}{6}=71,165 \\
\mathrm{a} & =87,92-0,29(71,165) \\
& =67,28 . \\
\text { Jadi } Y=67,28+0,29(71,165) & =87,92
\end{aligned}
$$

Persamaan ini memiliki arti jika $\mathrm{X}$ bertambah satu satuan nilai, maka $Y$ akan bertambah sebesar 0,29. Mencari koefisien korelasi, dengan rumus:

$$
\begin{aligned}
r_{x y} & =\frac{\sum X Y}{\sqrt{ }\left(\sum X^{2}\right)\left(\sum Y^{2}\right)} \\
& =\frac{37742,6216}{\sqrt{ }(31071,2551)(46595,6037)} \\
& =0,99
\end{aligned}
$$

Pengolahan data dengan t-test

$$
\begin{aligned}
t_{0} & =\frac{r \sqrt{ } n-2}{\sqrt{ } 1-r^{2}} \\
& =\frac{0,99 \sqrt{ } 6-2}{\sqrt{0} 1-0,98} \\
& =14,14
\end{aligned}
$$

Berdasar $t$ table didapat: $t_{0}, 05(6)=0,811$. Jadi $14,14>0,811$. Berarti hubungan pendidikan anak usia dini dengan prestasi siswa kelas 1 sekolah dasar secara bersamasama untuk Kabupaten dan Kota adalah sangat kuat

(signifikan). Hipotesis diterima.

\section{Simpulan dan Saran Simpulan}

Atas dasar temuan studi disimpulkan bahwa:

1) Terdapat perbedaan prestasi yang signifikan antara siswa kelas I sekolah dasar asal pendidikan anak usia dini (formal) dengan nonformal/informal, baik siswa dari Kabupaten maupun Kota Tangerang. Dalam banyak aspek siswa dari Kota memperlihatkan nilai lebih tinggi dari pada siswa dari Kabupaten; 2) Perbedaan prestasi antara siswa asal 
pendidikan anak usia dini (formal) dengan nonformal/informal di Kabupaten Tangerang adalah sbb: (a) Aspek intelektual, yaitu 85,77:71,38. Perbedaannya sebesar 14,39; (b) Aspek psikomotorik, nilai dan sikap $=72,99: 49,45$. Perbedaannya 22,83; dan (c) Aspek questionnaire $=61,25$. Perbedaan prestasi antara siswa asal pendidikan anak usia dini (formal) dengan nonformal/informal di Kota Tangerang adalah sbb: a) Aspek intelektual adalah 90,07: 70,95. Perbedaannya sebesar 19,12 ; b) Aspek psikomotorik, nilai dan sikap adalah 74,44:60,65. Perbedaannya 13,79; dan c) Aspek questionnaire. adalah 73,33; dan 3) Berdasrkan hasil perhitungan dengan analisis persentase maupun analisis statistik dengan t-test, tampak nilai-nilai yang diperoleh siswa asal pendidikan anak usia dini (formal) lebih tinggi dibanding dengan siswa non-formal/informal, baik di Kabupaten maupun di Kota Tangerang. Ini berarti pendidikan prasekolah berpengaruh terhadap pencapaian prestasi belajar siswa di kelas I sekolah dasar di
Kabupaten dan Kota Tangerang, tahun pelajaran 2008/2009.

\section{Saran}

Berdasarkan simpulan, maka disarankan agar: 1) untuk meningkatkan kemampuan intelektualitas, psikomotorik serta nilai dan sikap siswa di kelas I sekolah dasar di Kabupaten dan Kota Tangerang, maka perlu dianjurkan memasuki pendidikan anak usia dini, bahkan bila mungkin diatur dalam peraturan daerah (Perda) yang disertai dengan faktor-faktor pendukung-nya, seperti personal, biaya ataupun lainnya; 2) Di masa mendatang sangat dibutuhkan individu-individu yang berpotensi tinggi guna membangun Kabupaten dan Kota Tangerang, sehingga unsur kehidupan apa pun yang disandang, mereka sudah memiliki bekal dalam human capacity development (HCD), yang bermuara pada optimalisasi seluruh potensi individu. Pada gilirannya mereka mampu mengembangkan diri berdasar potensinya.

\section{Pustaka Acuan}

Alwi, Hasan. 2001. Kamus Besar Bahasa Indonesia. Jakarta: Depdiknas dan Balai Pustaka.

Anam, Saiful. 2007. Jangan Meremehkan Taman Kanak-kanak, Taman Yang Paling Indah. Solo: Wajatri.

Arikunto, Suharsimi. 1998. Prosedur Penelitian. Jakarta: Rineka Cipta.

Azhari, Akyas. 1996. Psikologi Pendidikan. Semarang: Dina Utama.

Departemen Pendidikan Nasional. 2003. Pendidikan Usia Dini, Taman Kanak-kanak dan Raudlatul Atfal, Standar Kompetensi. Jakarta.

Hakim, Aceng Lukman. 1996. Pengantar Ilmu Pendidikan. Tangerang: Diktat kuliah.

Hainstock, Elizabeth G. Hermes. 2002. Montessori Untuk Sekolah Dasar. Jakarta: Delapratasa Publishing.

Isya, Hilman. 2005. Menyiapkan Pendidikan Dini. Dinamika Umat Majalah Depag Banten, no. 28/IV/ Februari.

Mikarsa, Hera Lestari, 2007. Pendidikan IPS di SD. Jakarta: UT.

Purwanto, M. Ngalim. 1998. IImu Pendidikan, Teoritis dan Praktis. Bandung: Remaja Rosdakarya.

R. Moelichatoen. 2004. Metoda Pengajaran di Taman Kanak-kanak. Jakarta: Rineka Cipta dan Depdikbud.

Rusyan, A. Tabrani. 2000. Upaya Meningkatkan Budaya Kinerja Guru Sekolah Dasar. Cianjur: Dinamika Karya Cipta.

Sudiyono, Anas. 2008. Pengantar Statistik Pendidikan. Jakarta: Raja Grafindo Persada.

Sudjana, Nana. 1996. Cara Belajar Siswa Aktif dalam Proses Belajar Mengajar. Jakarta: Sinar Baru.

Syah, Muhibbin. 1996. Psikologi Pendidikan dengan Pendekatan Baru. Bandung: Remaja Rosdakarya.

Tim Dosen IKIP Malang. 1998. Pengantar Dasar-dasar Kependidikan. Surabaya: Usaha Nasional.

Undang-Undang Republik Indonesia, Nomor 20 Tahun 2003 tentang Sistem Pendidikan Nasional.

Jakarta: Mini Jaya Abadi.

Winkel, WS. 1991. Psikologi Pengajaran. Jakarta: Grasindo. 